\title{
Xylem anatomy of Robinia pseudoacacia L. and Quercus robur L. is differently affected by climate in a temperate alluvial forest
}

\author{
Paola Nola $^{1}$ (D) $\cdot$ Francesco Bracco $^{1} \cdot$ Silvia Assini ${ }^{1} \cdot$ Georg von Arx $^{2} \cdot$ Daniele Castagneri $^{2}$
}

Received: 22 July 2019 / Accepted: 24 November 2019 / Published online: 10 January 2020

(C) INRA and Springer-Verlag France SAS, part of Springer Nature 2020

\begin{abstract}
- Key message Xylem hydraulic traits of native Quercus robur are more sensitive to previous-summer drought than those of alien Robinia pseudoacacia. The latter modulates vessel traits and ring porosity to cope with inter-annual climate variability, and is less affected by extreme events. This suggests that $R$. pseudoacacia might be more competitive under future drier conditions.

- Context Forest management strategies require knowledge on how co-occurring native and alien species respond to unprecedented climate conditions, which can severely affect xylem conductivity and tree performance.

- Aims We aimed at quantitatively comparing xylem anatomical traits of co-occurring native Quercus robur and alien Robinia pseudoacacia and assessing similarities and differences in their response to climate variability.

- Methods We analyzed tree-ring anatomy and built chronologies of several parameters related to vessel number, size, and theoretical conductivity. Mean chronologies for each parameter were correlated to monthly temperature and precipitation data for the period 1954-2005 and within 30-year moving windows. We also assessed responses to extreme conditions in 2003.

- Results Quercus robur showed typical ring-porous vessel distribution, while $R$. pseudoacacia modulated vessel size and number year by year, frequently showing semi-ring porous appearance. Previous rainy summers increased size of large vessels in $Q$. robur, and number of large vessels in $R$. pseudoacacia. In winter, $R$. pseudoacacia was sensitive to water excess. High temperature in March increased vessel size in $Q$. robur, but reduced it in $R$. pseudoacacia. The 2003 summer heatwave strongly reduced vessel size and number in the following year in $Q$. robur, but had much less effect on $R$. pseudoacacia.

- Conclusion Quercus robur xylem traits are more influenced by both inter-annual climate variability and extreme events than those of $R$. pseudoacacia. Lower performance under dry conditions might reduce competitiveness of $Q$. robur in the future, slowing down the natural replacement of the invasive pioneer $R$. pseudoacacia by later-stage $Q$. robur.
\end{abstract}

Keywords Alien species $\cdot$ Black locust $\cdot$ Climate response $\cdot$ Drought $\cdot$ Pedunculate oak $\cdot$ Tree-ring anatomy $\cdot$ Vessel

\section{Handling Editor: Cyrille B. K. Rathgeber}

Contributions of the co-authors PN designed the study. PN, FB and SA conducted field work. PN, GvA, and DC processed the samples and analyzed data. PN and DC wrote the first paper draft. All authors contributed to discussion of results and writing the manuscript.

This article is part of the topical collection on Wood formation and tree adaptation to climateRisk Analysis

Paola Nola

paola.nola@unipv.it

1 Department Earth and Environmental Sciences, University of Pavia, Pavia, Italy

2 Swiss Federal Institute for Forest Snow and Landscape Research WSL CH-8903 Birmensdorf, Birmensdorf, Switzerland

\section{Introduction}

During their long life span, trees are naturally exposed to large intra- and inter-annual variations in temperature and water availability. However, ongoing climate change, including increasing mean temperature and frequency of heatwaves, as well as reduction of summer precipitation in Western and Southern Europe (Giorgi and Lionello 2008), is exposing trees to unprecedented stressful conditions. Most European forests will be heavily affected by climate change in the next decades (Bussotti et al. 2015), with severe impacts on their carbon sequestration capacity (Ciais et al. 2005), economic value (Hanewinkel et al. 2013), and ecosystem services (Bonan 2008).

Whether future warmer conditions might favor alien over native species is an important issue in forest management 
(Dyderski et al. 2018). For example, Northern-American Pseudotsuga menziesii Mirb. is less vulnerable to soil water deficits than the co-occurring European Picea abies (L.) Karst. (Lévesque et al. 2013), and Chinese Ailanthus altissima (Mill.) Swingle shows a higher drought resistance than the cooccurring Castanea sativa Mill. (Knüsel et al. 2015). Therefore, in some European regions, we might expect that alien species well-adapted to future conditions will partially replace native ones (Dyderski et al. 2018). At sites where native and alien species coexist, this perspective calls for comparative studies on their responses to climate, which can be performed in many ways.

One of the most widely used approaches is to investigate tree-ring series to retrospectively assess how inter-annual climate variability, or extreme climate events, affected past growth patterns and to infer a species' or population's capacity to cope with future conditions (Fritts 1976). Besides ring width, xylem anatomical features in tree rings can provide additional information on climate influence on functional traits related to efficiency and safety of water transport (De Micco et al. 2019; Fonti et al. 2010). Xylem hydraulic conductivity depends on conduit lumen size and number, in addition to other microscopic features such as inter-vessel pitting (Cruiziat et al. 2002). Wide xylem conduits are more efficient than narrower ones, but more prone to freeze-thaw induced, and, arguably, to drought-induced cavitation (Hacke et al. 2017). In addition, a higher number of conduits obviously improves water transport capacity (Hacke and Sperry 2001). Favorable climate conditions during xylem formation (Fonti et al. 2007; García-González and Eckstein 2003), or in the previous season, especially in ring-porous species (GeaIzquierdo et al. 2012; Martínez-Sancho et al. 2017), allow trees to form a higher number of and/or larger conduits than in unfavorable years. However, responses are very variable from species to species, due to different growth strategies and xylem anatomy (Castagneri et al. 2017; GonzálezGonzález et al. 2014). Species able to form a relatively more efficient xylem structure under future climate conditions would be more competitive. Furthermore, trees with large vessels, highly vulnerable to expected drier conditions, might have lower chances of surviving during severe drought events (Olson et al. 2018). Knowing how coexisting alien and native species respond to climate conditions, especially in terms of safety and efficiency of their xylem structure, may be crucial in assessing the future spread of alien tree species in Europe, and their ability to outcompete native species (Cavalieri and Sack 2010). Surprisingly, while many studies have been performed on the xylem responses to climate of European native broadleaf species, studies on alien species are scant.

In this study, we investigated native pedunculated oak (Quercus robur L.), one of the main species in temperate deciduous mixed forests in central Europe, and the alien black locust (Robinia pseudoacacia L.), naturalized and invasive in most European countries (Cierjacks et al. 2013), to compare their growth response to climate by quantitative xylem analysis. The study site, along the Ticino river, hosts one of the few and best-conserved relicts of the original alluvial forests in Northern Italy (Sartori 1984). This forest has gone unmanaged for many decades (Motta et al. 2009), allowing the study of interrelationships between climate and tree growth without the strong human disturbances typical of European lowlands.

However, in mesic sites, radial growth is not controlled by a single limiting factor, and it may be difficult to identify climatic signals within tree-ring series (Fonti and GarcíaGonzález 2008; Tessier et al. 1994). In such circumstances, xylem anatomical traits, being directly related to physiological processes, might be more effective in comparing the responses of the two species to climate.

We designed this study in order to: (1) quantify the main differences in xylem anatomical traits between the two species and their inter-correlation; (2) assess the main climatic factors influencing xylem traits and tree growth, and any temporal trend in the responses linked to climate change; and (3) evaluate the effects of the summer 2003 climate extreme on the species xylem traits.

\section{Methods}

\subsection{Study area and target species}

The study site is located in the "Siro Negri" State Natural Forest Reserve, established in 1970 within the Ticino Regional Park, Northern Italy $\left(45^{\circ} 12^{\prime} \mathrm{N}, 9^{\circ} 03^{\prime} \mathrm{E}, 63 \mathrm{~m}\right.$ a.s.l.) and covering $11 \mathrm{ha}$. The Reserve protects a mixed broadleaved forest attributed to Habitat 91F0 (riparian mixed forests of hardwood trees on the banks of large rivers, liable to flooding), in accordance with Directive 92/43/EEC and it is included in an EU Site of Community Interest. Previous studies have shown that the forest is dense, structurally complex, and rich in biomass, as expected for stands unmanaged for decades. The stand is dominated by Quercus robur; other tree species are Robinia pseudoacacia, Ulmus minor Mill. Carpinus betulus L., Populus alba L., and Acer campestre L. (see Motta et al. 2009 for detailed characteristics of the stand, such as other co-occurring species, density and treeage). Mean annual precipitation is about $800 \mathrm{~mm}$ and mean annual temperature is $13.6{ }^{\circ} \mathrm{C}$ (Pavia weather station, $10 \mathrm{~km}$ from the study site, for a climatic diagram see Annex Fig. 8). Floods occur in spring or autumn every 5-10 years (Castagneri et al. 2013). Except during such events, groundwater level is around $-4.50 \mathrm{~m}$ in winter, while it reaches $3.50 \mathrm{~m}$ during summer, due to irrigation of corn and rice fields in the surroundings (Sartori unpublished).

Within the study site, we focused on tree-ring anatomy of Quercus robur and Robinia pseudoacacia. Q. robur is ring- 
porous, with very large vessels in the earlywood, while latewood presents much smaller vessels in radially oriented aggregates (Schweingruber 1990). Robinia pseudoacacia is considered ring-porous too, but shows more gradual transition of vessel size from earlywood to latewood (Schweingruber 1990).

\subsection{Sample collection and wood preparation}

Increment cores were taken with Pressler's borers at $1.3 \mathrm{~m}$ above ground from adult dominant or co-dominant $Q$. robur and $R$. pseudoacacia trees between 2005 and 2013. Of the collected samples, a total of 10 Q. robur and 15 R. pseudoacacia cores were analyzed for anatomical traits in the present study. Given the higher variability of ring structure in $R$. pseudoacacia (Fig. 1) a larger number of samples was analyzed for this species. The samples were mounted on fixed supports and cut with a razor blade to obtain a flat surface. To enhance the contrast between conduit lumen and wood matrix, $Q$. robur vessel lumina were filled with white chalk powder (Gärtner and Schweingruber 2013). Giving the natural dark color of the wood matrix (due to the abundance of tannins),
Fig. 1 Wood and vessel characteristics in Quercus robur (left) and Robinia pseudoacacia (right). a Wood surface after preparation. In R. pseudoacacia, red squares highlight rings with large vessels concentrated in earlywood (clearly ring porous), blue squares highlight rings with vessel sizes gradually declining across the ring (semi-ring porous appearance). b Vessel area spatial distribution within the ring, in the two species. Dots represent the area of each vessel and its percentage distance from the earlywood ring border. The solid line represents the mean value, the dashed lines indicating one standard deviation. c Vessel size frequency distribution

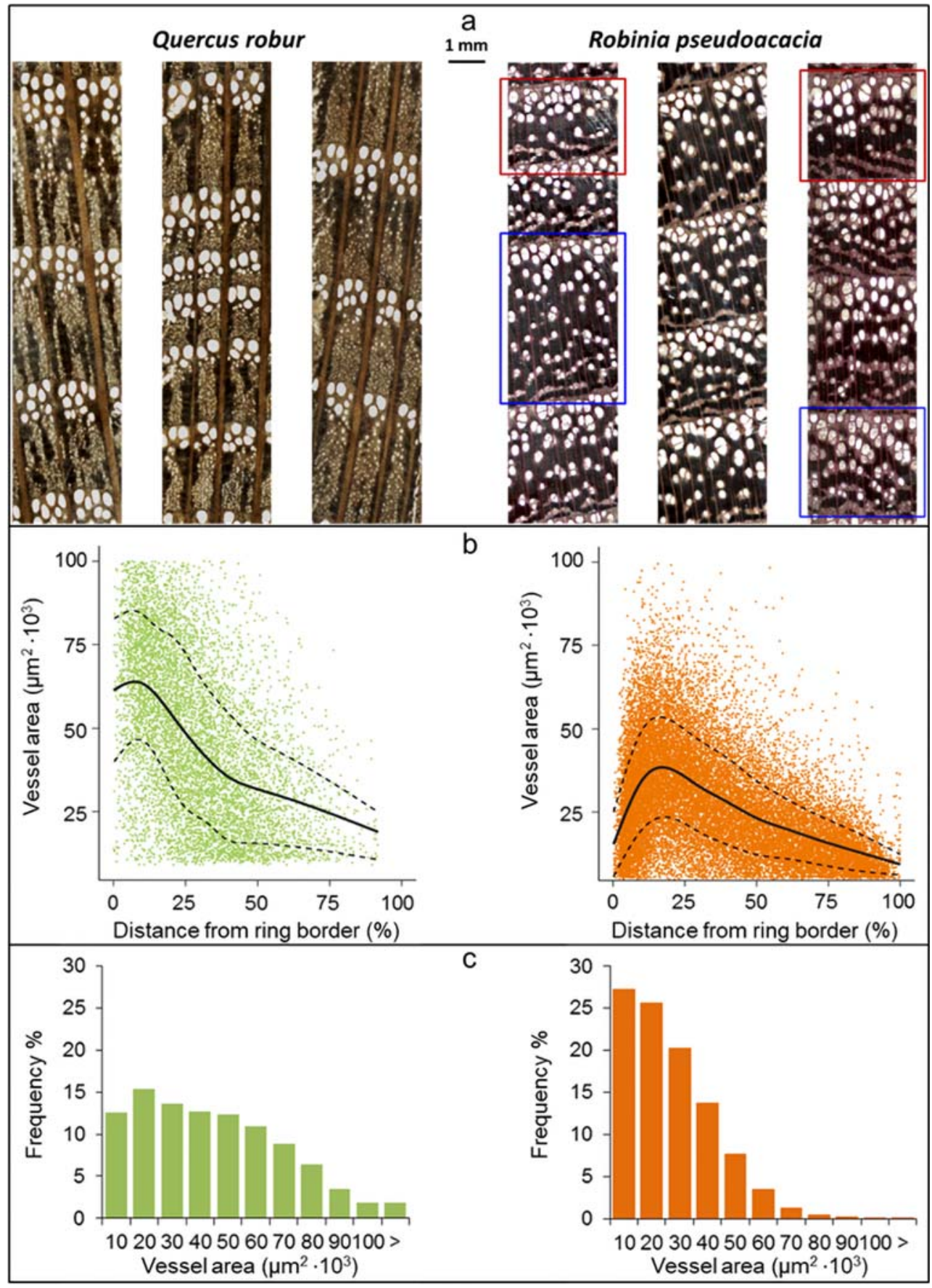


the contrast with white chalk in vessel lumina was strong, therefore no further processing was required before image acquisition with a scanner. On the other hand, $R$. pseudoacacia samples needed additional preparation due to the brighter color of the wood matrix and abundance of light parenchyma bands: heartwood was colored with phloroglucinol, while sapwood was colored with phloroglucinol and potassium iodide-iodine (Kutscha and Sachs 1962). After drying, vessels were filled with white chalk powder. The cores were then scanned using an Epson V700 Photo Scanner (Seiko Epson Corporation, Suwa, Nagano, Japan) at 2400 dpi resolution and 48-bit color depth.

\subsection{Tree-ring data, vessel parameters, and chronology building}

Tree-ring width was measured on all the cores to the nearest $0.01 \mathrm{~mm}$ using a CCTRMD device (Aniol 1987), and crossdated using the mean chronologies derived for the two species from previous studies (Motta et al. 2009; Nola 1996; Tessier et al. 1994). Statistics commonly used in dendrochronology were computed to describe key properties of ring-width chronologies (Fritts 1976): mean sensitivity (MS) and standard deviation (SD) were used to assess high-frequency variation of the series; first-order serial autocorrelation (AC) to detect persistence within the series; and mean correlation between trees (rbar) to measure the common variance between individual series.

Within dated tree rings in the common period 1954-2005, vessels in a 3-mm wide radial strip were measured on digital images using ROXAS software (von Arx and Carrer 2014), which provided the lumen size and centroid position for each vessel within dated annual rings. The lower threshold for vessel detection was set to $5000 \mu \mathrm{m}^{2}$ (García-González et al. 2016), a limit compatible with the image resolution and suitable for detecting vessels in both species. This threshold was lower than that commonly used for ring-porous species, frequently set to $10,000 \mu \mathrm{m}^{2}$ (García-González and Fonti 2008), ignoring only the smallest vessels while retaining the larger vessels that contain the strongest environmental signal (Fonti et al. 2009; García-González et al. 2016). The following parameters were assessed for each ring: mean ring width (RW); number of vessels (VN); total vessel lumen area (TVA); net wood area (NWA) as the difference between total ring area and TVA, representing the part of the ring not devoted to water transport; mean hydraulically-weighted diameter (Dh), calculated according to Tyree and Zimmermann (2002); and theoretical hydraulic conductivity $(\mathrm{Kr})$, i.e., the sum of theoretical hydraulic conductivity (as approximated by Poiseuille's law and adjusted to elliptical tubes) of all the vessels in a ring (Castagneri et al. 2015; González-González et al. 2015).

Since environmental responses can be maximized by filtering vessels according to their size (García-González et al.
2016), we also calculated the Dh for vessels larger than the first (Q1Dh) and smaller than the last (Q4Dh) quartiles of size distribution, the total area of the three largest vessels (Max3) and the area corresponding to the 10th (A10), 50th (A50), and 90th (A90) percentile. Finally, we calculated the number of vessels larger than the mean vessel size (NL).

As individual series of ring width and anatomical traits may be affected by age/size trend (Carrer et al. 2015), they were detrended by cubic smoothing spline function with a $50 \%$ frequency cutoff response at 100 years, using the ARSTAN program (Cook and Krusic 2005). Successively, spline function with a $50 \%$ frequency cutoff response at 20 years was applied to keep the high-to-medium series frequency, usually related to inter-annual climatic variability (Cook and Peters 1981). An autoregressive function was then used to eliminate autocorrelation (Tessier et al. 1994). The obtained residual series were then averaged by a bi-weight robust mean into a chronology for each species and variable. The same method was applied to all the variables to avoid differences associated with detrending procedures (González-González et al. 2014).

\subsection{Statistical analyses}

To explore the relationships between the ring and vessel chronologies in each species (González-González et al. 2015), we applied principal component analysis (PCA) computed on the chronologies correlation matrix for the common period 1954 2005.

To evaluate the influence of the previous year's growth ( $\mathrm{t}$ 1) on the anatomical traits in the current one $(t)$, we calculated Pearson's correlation for each vessel variable $(\mathrm{t})$ with $\mathrm{RW}$ and NWA (t-1). Then the correlation between TVA and NWA was studied at decreasing lags starting from the current year. The analysis was conducted on residual series to assure that any possible significant correlation did not reflect residual autocorrelation within the series.

Further, to evaluate whether inter-annual variability of anatomical traits was related in $Q$. robur and $R$. pseudoacacia, we calculated paired correlations between all the ring and vessel chronologies for the two species.

The influence of climate on xylem traits was investigated using monthly temperature and precipitation data from CRU TS 3.22 climate grids $(0.5 \times 0.5$ degree) (Harris et al. 2014). Relationships between the 13 chronologies for each species and climate from June of the year preceding ring formation to July of the current ring formation year were investigated by means of Pearson's correlation function.

We also assessed temporal variations of climate influence on anatomical traits, by means of 30 -year moving correlation functions between the climatic variables and the 13 chronologies (Biondi and Waikul 2004; Carrer et al. 2010; Lebourgeois et al. 2012). 
Finally, we investigated the effects of summer 2003-the warmest and driest one in the study period - on ring and vessel parameters in the 2003 and 2004 rings for the two species. Specifically, we calculated the ratio between each parameter for the target years (2003 and 2004), and its mean value in the 3 years prior to the event (2000-2002), considered as reference (Castagneri et al. 2017; Lloret et al. 2011). After testing for normal distribution and equal variance, differences between the parameters in the target years and in the reference period were assessed by paired Student's $t$ test.

\section{Results}

\subsection{Tree ring and vessel parameters}

Quercus robur individuals were larger and older and showed higher growth rates (mean ring width), mean sensitivity (MS), and autocorrelation (AC) than $R$. pseudoacacia individuals (Table 1). Rbar was similar for the two species. Xylem anatomical features of the species were quite different (Fig. 1a). In Q. robur, large vessels were confined to the proximity of the early ring border and their size decreased abruptly (Fig. 1b), so that few vessels above the selected threshold were detectable moving away from the border. In R. pseudoacacia, vessel size was highly variable. In some rings, small vessels occurred even in the early part of the ring, mixed with or preceding the large ones. Porosity was highly variable, too. While some rings showed ring porosity typical of the species, some others were semi-ring porous, with conduits above the selected threshold occurring along the entire ring. The frequency distribution of vessel size also showed different patterns (Fig. 1c). In $Q$. robur, vessel frequency was quite uniform in the first-size classes and it gradually decreased for vessels over $60,000 \mu^{2}$. In $R$. pseudoacacia, the size distribution approximated a reverse J-shape, with a peak around $15,000 \mu^{2}$ and more than $50 \%$ of the vessels smaller than $25,000 \mu^{2}$. Vessels $>75,000 \mu \mathrm{m}^{2}$ were rare.
The Kolmogorov-Smirnov test detected significant differences between the two species for all the investigated parameters $(p<0.01$, Table 2$)$. RW, NWA, and all parameters related to vessel number (VN, NL, TVA) were higher in R. pseudoacacia. Quercus robur had higher values for vessel-size parameters. $\mathrm{Kr}$, linked to both vessel size and number, was higher in $R$. pseudoacacia.

\subsection{Interrelationships between parameters and species}

The PCA ordination (Fig. 2) showed similarities and differences between the two species. For both species, the two first PCs together explained about $69 \%$ of total variance. The third PC accounted for about $13 \%$, but added significant information only for R. pseudoacacia (Broken-Stick Model, Jackson 1993, see the scree plot in Annex Fig. 9).

For both the species, $\mathrm{PC} 1$ was positively related with most parameters (see also the correlation of PC axes with each parameter in Annex Fig. 10). PC2, more important for $R$. pseudoacacia than for $Q$. robur, showed that parameters that depend on vessel size were more separated from those linked to vessel number (and ring width) in $R$. pseudoacacia than in $Q$. robur. This difference was underlined by the negative correlation between $\mathrm{A} 50$ and $\mathrm{VN}$ in $R$. pseudoacacia, not detectable in $Q$. robur (Annex Fig. 11). Finally, PC3 separated small (A10, Q4Dh) from large vessels.

For $Q$. robur, previous years' RW and NWA correlated with some vessel parameters for the current year (correlation positive with VN, NL, TVA, Kr, and negative with Q4Dh), while no correlation was found for $R$. pseudoacacia (Fig. 3). In particular, TVA correlated with the NWA of both the previous (lag -1) and the current (lag 0 ) year in $Q$. robur, but only with the current NWA in R. pseudoacacia (Fig. 4).

A positive association was found between the two species' RW, NWA, and A50 chronologies. None of the other parameters showed significant correlation, evidencing different inter-annual variability in the two species (Annex Fig. 12).
Table 1 Tree characteristics and descriptive statistics for raw treering width chronologies

\begin{tabular}{lll}
\hline & Quercus robur & Robinia pseudoacacia \\
\hline Number of trees & 10 & 15 \\
Mean diameter (range) [cm] & $62(50-77)$ & $38(27-54)$ \\
Mean age (range) & $104(83-148)$ & $63(57-73)$ \\
Chronology time span [years] & $1876-2012(137)$ & $1946-2012(67)$ \\
Mean ring width [mm] & 2.292 & 2.079 \\
Standard deviation [mm] & 1.158 & 0.797 \\
Mean sensitivity (MS) & 0.234 & 0.187 \\
First-order correlation (AC1) & 0.827 & 0.739 \\
Mean series inter-correlation (Rbar) & 0.386 & 0.394 \\
\hline
\end{tabular}


Table 2 Tree-ring and vessel parameters of the investigated species in the period 1954-2005: acronym, definition, unit, mean and standard error (SE). All parameters are statistically different between the two species (Kolmogorov-Smirnov test, $p<0.01$ )

\begin{tabular}{|c|c|c|c|}
\hline Acronym & Tree-ring or vessel parameter & $\begin{array}{l}\text { Quercus robur } \\
\text { Mean } \pm \text { SE }\end{array}$ & $\begin{array}{l}\text { Robinia pseudoacacia } \\
\text { Mean } \pm \text { SE }\end{array}$ \\
\hline RW & Tree-ring width $[\mathrm{mm}]$ & $1.88 \pm 0.05$ & $2.02 \pm 0.04$ \\
\hline NWA & Net wood area $\left[\mathrm{mm}^{2}\right]$ & $4.87 \pm 0.14$ & $5.19 \pm 0.09$ \\
\hline $\mathrm{VN}$ & Vessel number & $16 \pm 0.2$ & $32 \pm 0.6$ \\
\hline NL & Number of vessels larger than the mean & $9 \pm 0.1$ & $14 \pm 0.2$ \\
\hline TVA & Total vessel area $\left[\mathrm{mm}^{2}\right]$ & $0.78 \pm 0.01$ & $0.86 \pm 0.02$ \\
\hline $\mathrm{Kr}$ & Theoretical hydraulic conductivity $\left[\mathrm{kg} \mathrm{m} \mathrm{MPa}^{-1} \mathrm{~s}^{-1}\right]$ & $1.65 \pm 0.03$ & $1.38 \pm 0.03$ \\
\hline $\mathrm{Dh}$ & Mean hydraulic diameter $[\mu \mathrm{m}]$ & $262 \pm 1.4$ & $201 \pm 0.7$ \\
\hline Max3 & Mean lumen area of the three largest vessels $\left[\mu \mathrm{m}^{2}\right]$ & $83,252 \pm 852$ & $55,631 \pm 419$ \\
\hline A90 & Vessel lumen area corresponding to 90 th percentile $\left[\mu \mathrm{m}^{2}\right]$ & $79,021 \pm 827$ & $47,384 \pm 350$ \\
\hline Q1Dh & Hydraulic diameter for vessels over 75 th percentile $[\mu \mathrm{m}]$ & $319 \pm 1.6$ & $249 \pm 0.9$ \\
\hline A50 & Vessel lumen area corresponding to 50 th percentile $\left[\mu \mathrm{m}^{2}\right]$ & $44,635 \pm 641$ & $25,348 \pm 227$ \\
\hline Q4Dh & Hydraulic diameter for vessels under 25 th percentile $[\mu \mathrm{m}]$ & $158 \pm 1.5$ & $123 \pm 0.6$ \\
\hline A10 & Vessel lumen area corresponding to 10 th percentile $\left[\mu \mathrm{m}^{2}\right]$ & $15,398 \pm 360$ & $9940 \pm 125$ \\
\hline
\end{tabular}

\subsection{Influence of climate on radial growth and xylem anatomy}

Differences between species were also evident in their response to climate (Fig. 5). In $Q$. robur, many parameters showed significant correlations with precipitation in the previous summer (June-July): negative for RW and NWA, and positive for large vessel size (Max3, Q1Dh, A90, and A50). Very few significant correlations occurred between the investigated parameters and precipitation in the following months.
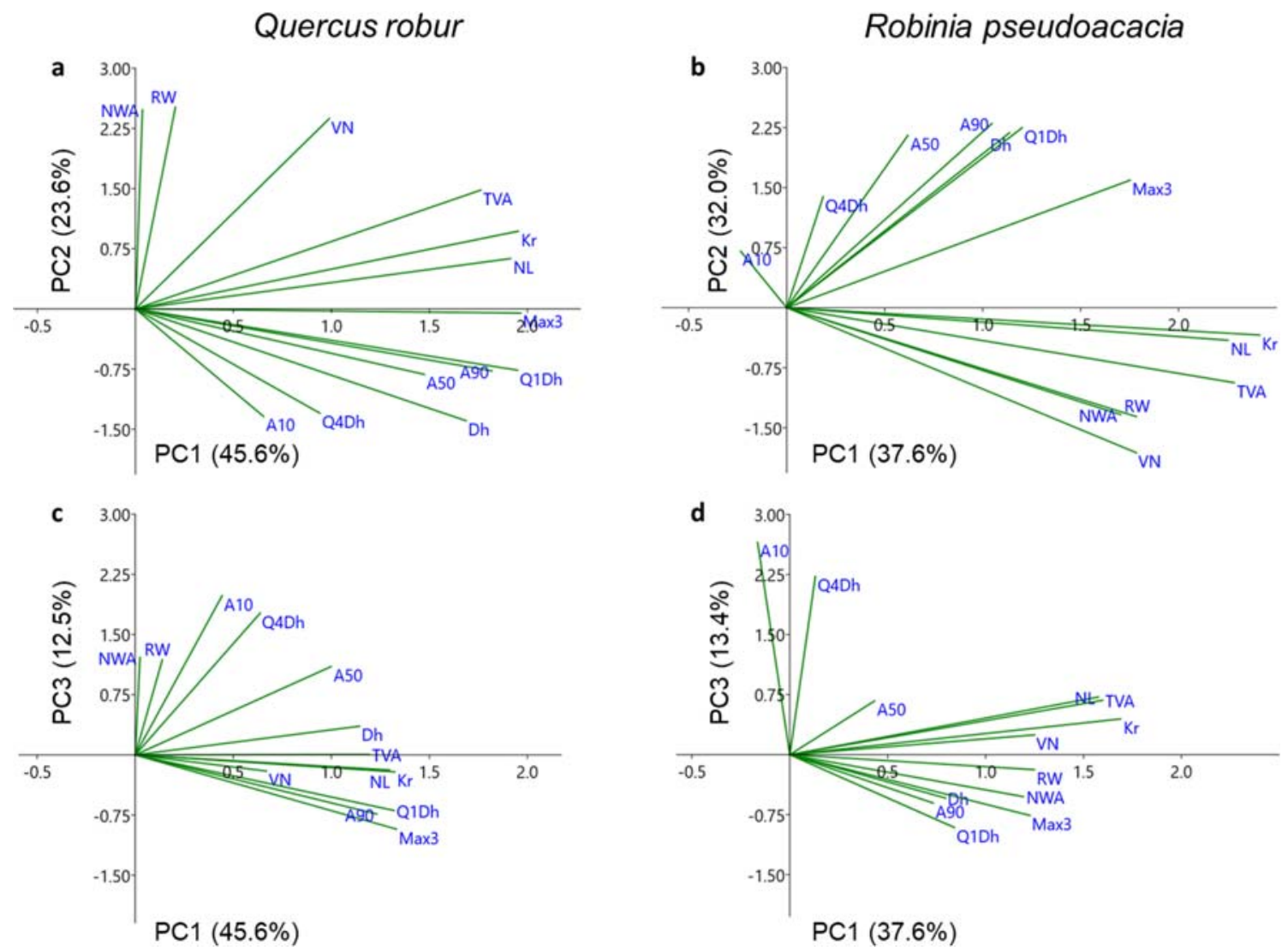

Fig. 2 Principal component analysis (PCA) of tree-ring width and vessel parameters. Acronyms are explained in Table 2. The upper plots show PC1 vs PC2, the lower ones, PC1 vs PC3 
Quercus robur

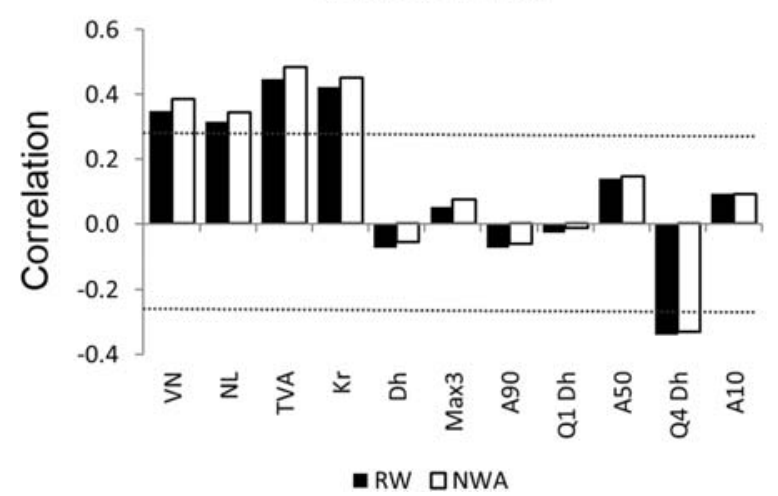

Robinia pseudoacacia

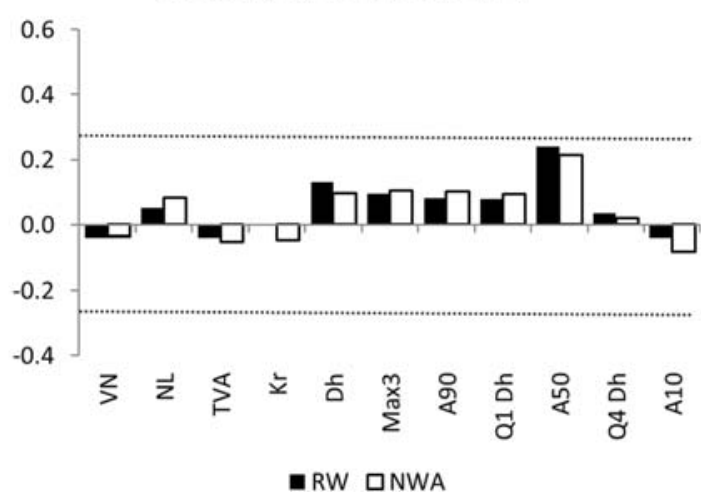

Fig. 3 Pearson s correlations of the residual chronology of each vessel parameter with ring width (RW) and with ring net wood area (NWA) chronologies for the previous year. Dotted lines indicate the level of significant correlation. Acronyms are explained in Table 2

Regarding temperature, negative correlations were found for previous summer (June-July for large vessels, August for $\mathrm{Kr}$ ) and for September (RW, NWA and VN). Correlations were positive for October (TVA, Kr, Max3, NL) and November (A50, A10), negative again for winter (December to February for TVA and VN), and returned to positive in the growing season (from March to June, for several vessel size parameters).

In $R$. pseudoacacia, significant correlations were more scattered. Precipitation in the previous summer correlated both negatively ( $\mathrm{Kr}$ in June) and positively (RW, Kr, NL in JulyAugust). Negative associations were found for the October (A90, Q4Dh) and December-February (TVA, Kr, Max3). In spring, precipitation correlated positively again, specifically during March (RW, NL) and May (TVA, NL, A10, Q4Dh). A few significant correlations with temperature were detected: positive for the previous October (A90, A50, Q4Dh) and current April (Q1Dh), and negative for December-February (Max3), March (Dh, Max3, Q1Dh, A90) and May (A10).

Moving correlation analysis showed that the relationships between climate and vessel parameters had stable, declining, or increasing trends during the study period (temporal variations for the parameters with the highest correlation in the entire period are shown in Fig. 6, complete results in Annex
Fig. 13). For $Q$. robur, positive correlations with previous June-July precipitations, previous October temperature, and April temperature remained stable over the study period, while the influence of December-February and March temperature were not significant in the recent decades. For $R$. pseudoacacia, the influence on vessel parameters of precipitation in the previous July-August and current May, remained stable over the period; while the effects of both precipitation and temperature in the previous October became significant only in the recent years. Chronology correlation with winter temperature and precipitation showed opposite trends, with a declining influence of temperature and increasing one of precipitation. In March, the trends reversed.

The two species responded differently to the 2003 heatwave, when May to August temperature in the region was $3.0{ }^{\circ} \mathrm{C}$ higher than, and precipitation less than $50 \%$ of the 1954-2005 average. The parameters of the ring formed in 2003 did not present any significant difference from the reference period in both species. However, most $Q$. robur parameters were noticeably lower in 2004 (Fig. 7), except for RW, NWA, A10, and Q4Dh. Anatomical parameters were much less affected in $R$. pseudoacacia, although a small but significant reduction was observed in large vessels (Dh, Max3, Q1Dh, and A90).
Fig. 4 Pearson's correlations between total vessel area (TVA) and ring net wood area (NWA) at decreasing lags starting from the current year (lag 0 ). Dotted lines indicate the level of significant correlation and solid bars refer to significant values

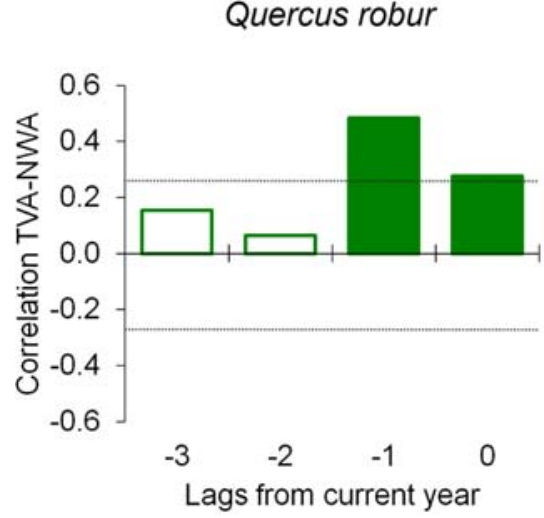

Robinia pseudoacacia

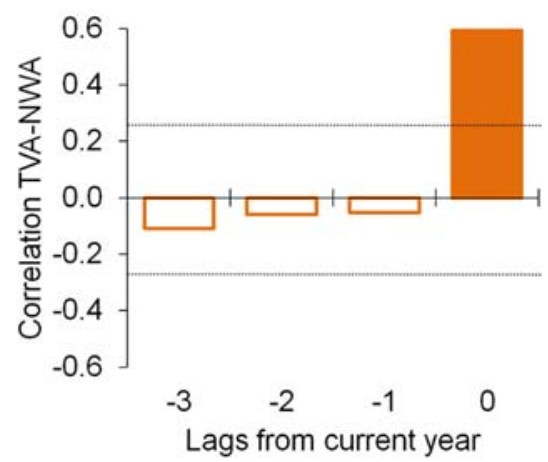


Fig. 5 Correlations between treering width and vessel parameters with monthly precipitation and temperature. Months of the previous year are in lowercase letters. Significance is coded according to the key at the bottom. Acronyms are explained in Table 2

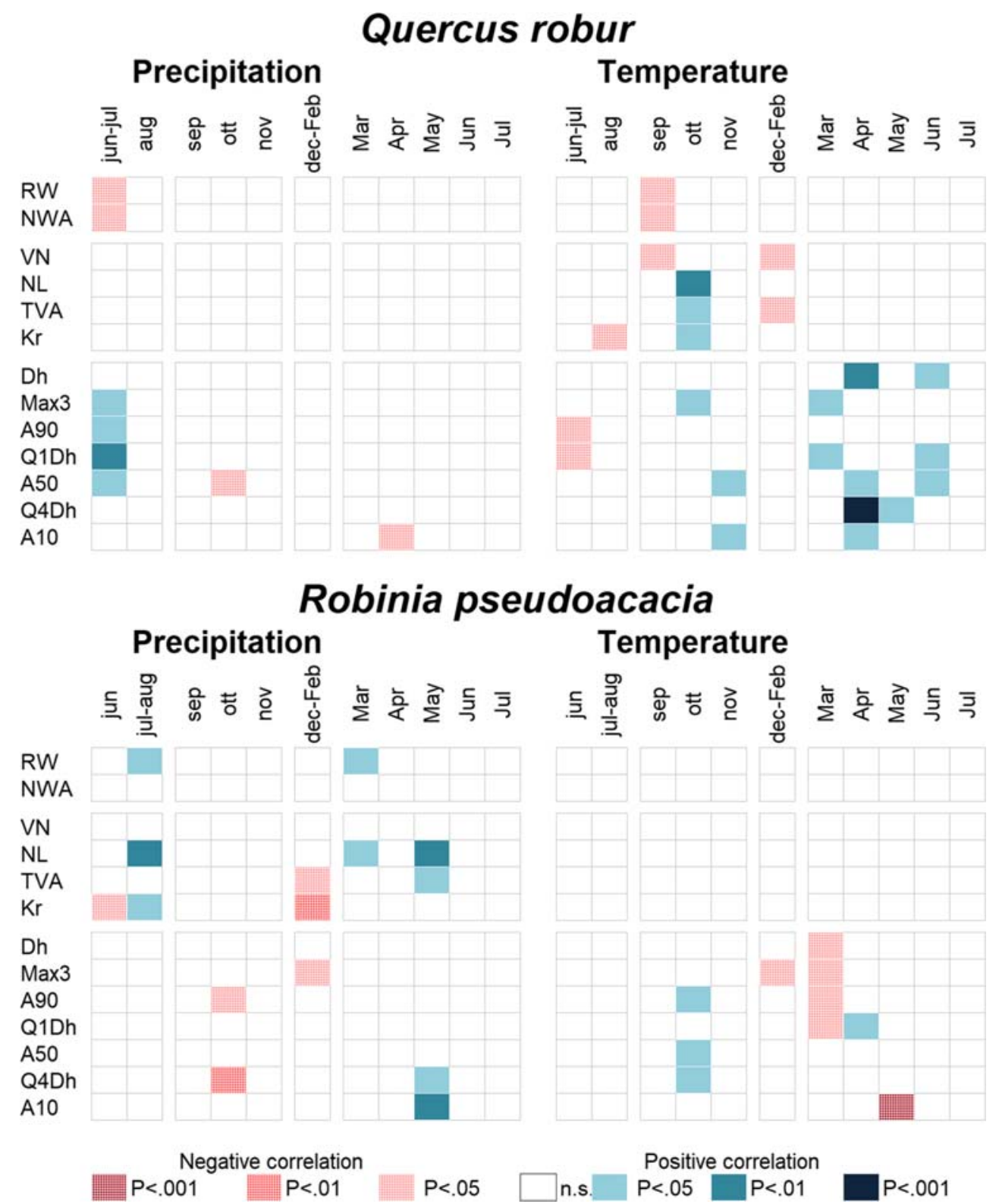

\section{Discussion}

\subsection{Tree-ring structure and xylem traits}

Both $Q$. robur and $R$. pseudoacacia wood are classified as ring-porous (Schweingruber 1990). However, our quantitative analysis showed marked differences in vessel size and frequency distribution within the rings, which might mediate their response to environmental constraints in the study area. The first vessels in $Q$. robur rings were much larger than in $R$. pseudoacacia. Very large vessels produced at the beginning of the growing season are highly efficient during a normally rainy spring (García-González and Fonti 2008; GarcíaGonzález et al. 2016). However, their functionality may be affected even in early summer by drought-induced embolism
(Pérez-de-Lis et al. 2018) or during winter by freeze-induced embolism (Hacke and Sperry 2001; Kitin and Funada 2016). By contrast, $R$. pseudoacacia produced a higher number of vessels that were significantly smaller and more scattered within the ring (Fig. 1, Table 2). Their spatial pattern differs year by year, sometimes showing a semi-ring porous appearance. This suggests that $R$. pseudoacacia has a more conservative strategy, prioritizing safety over efficiency, and settling for lower hydraulic conductivity (higher vessel number did not fully compensate for their smaller size, Table 2). Smaller earlywood vessels in $R$. pseudoacacia were likely functional for a longer time than those of $Q$. robur. Indeed, large vessels in $Q$. robur were filled with tyloses, both in the sapwood and in the hardwood. Differently, sapwood conduits in $R$. pseudoacacia (from three to seven rings) were empty, 

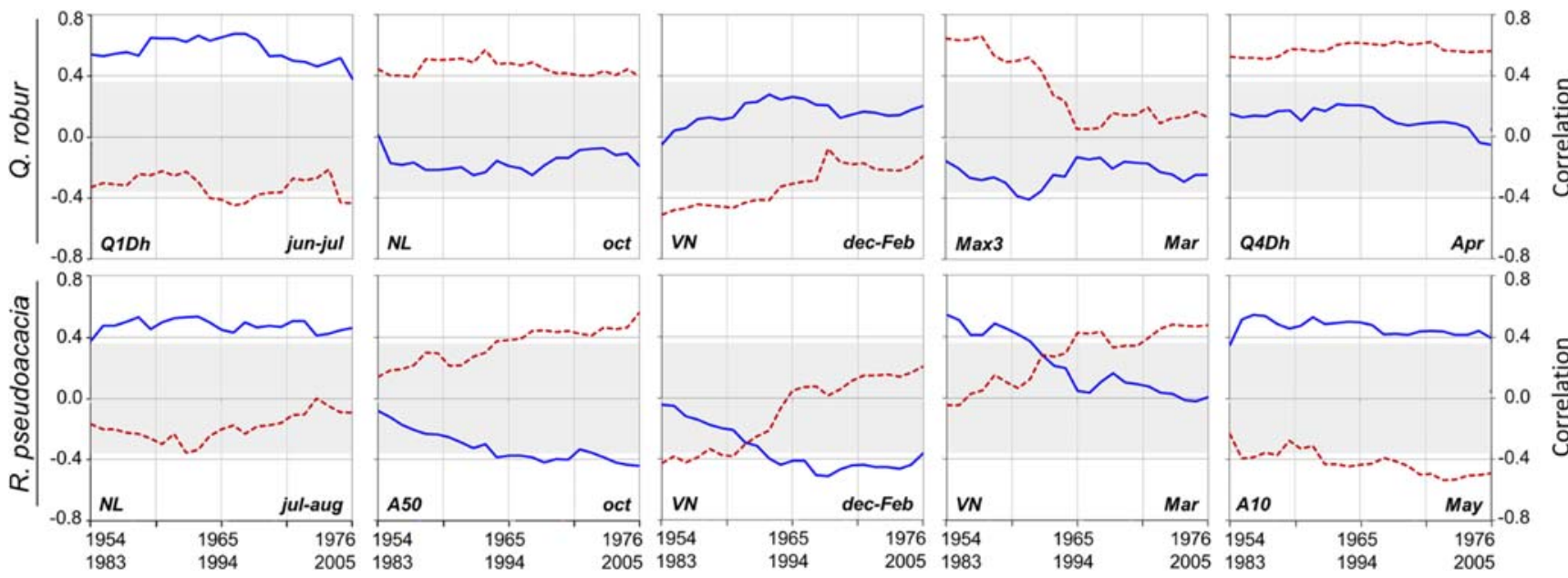

parameters and the climate variables are reported at the bottom left and right of the graphs, respectively. Shaded areas highlight non-significant values $(p \geq 0.05)$. Acronyms are explained in Table 2 climate variables over the period 1954-2005. Months of the previous are in lowercase letters. The solid lines indicate correlation with precipitation, the dashed lines correlation with temperature. The xylem species have shown that the formation of the current year's earlywood vessels starts before bud burst (Bréda and Granier 1996; Schmitt et al. 2000), and their maturation is completed only when small leaves are visible (Guada et al. 2019; Kitin and Funada 2016; Pérez-de-Lis et al. 2016b). As earlywood is formed before photosynthesis begins, its formation depends on available reserves, and on the ability of trees to mobilize them (Pérez-de-Lis et al. 2016a; Pérez-de-Lis et al. 2017; Kitin and Funada 2016). These processes explain our results, which are coherent with the relationships found in other studies between the previous year's ring-width (or latewood width) and vessel size (or earlywood width) (GarcíaGonzález and Eckstein 2003; Nola 1996; Souto-Herrero et al. 2017). On the contrary, no effect of the previous year's ring was observed in R. pseudoacacia xylem traits. Although no data are available on wood formation and phenology of $R$. pseudoacacia in our region, our results suggest that the early stages of vessel development for this species are less dependent on the previous year's reserves, as reported for diffuse-porous species (Zweifel et al. 2006).
Fig. 7 Percentage reduction in anatomical parameters in 2004 in Quercus robur and Robinia pseudoacacia. Solid bars indicate significant difference $(p<0.05)$ from the reference period 2000 2002. Acronyms are explained in Table 2

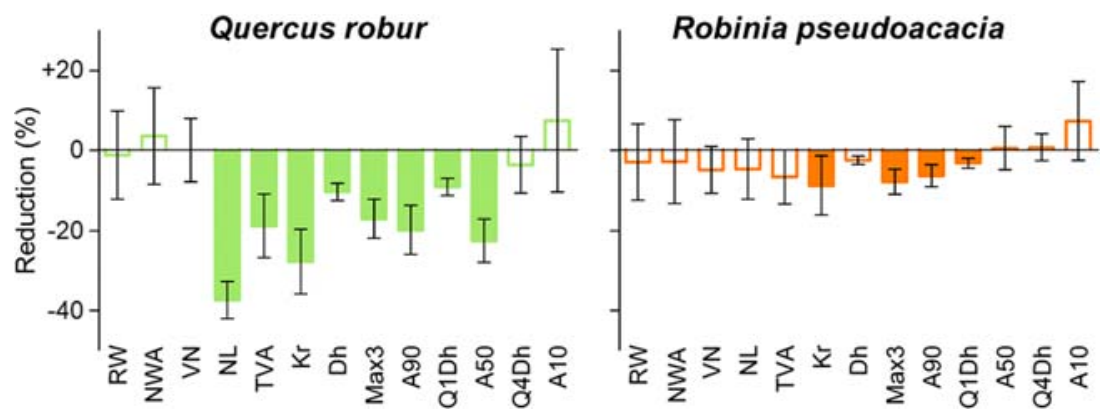




\subsection{Influence of climate on tree ring and vessel traits}

Our results showed that vessel traits of $Q$. robur and $R$. pseudoacacia were influenced by climatic conditions in physiologically distinct periods (Fig. 5): in the previous summer, during winter dormancy, and in the current growing season.

A previous rainy summer increased size of large vessels in Q. robur and the number of large vessels in R. pseudoacacia in the following growing season. Probably, rainfall during the previous summer improved the filling of carbon storage pools, facilitating the formation of either larger vessels or a higher number of large vessels at the beginning of the following season (González-González et al. 2014; Michelot et al. 2012). High temperature in the previous October positively influenced vessel parameters in both species. As cambial cell divisions originating the first vessel elements may occur at the end of the previous growing season, warm condition at that time may promote cell division, and the resulting cells overwinter with little or no further differentiation (Kitin and Funada 2016).

Warm conditions during dormancy negatively affected vessel development, mainly in $Q$. robur, as previously reported for several ring-porous species (Alla and Camarero 2012; Castagneri et al. 2017). High winter temperature is assumed to increase cell sensitivity to auxin, resulting in earlier and faster process of vessel differentiation, which leads to the formation of smaller vessels (Aloni and Zimmermann 1983; Akhmetzyanov et al. 2019). In addition, high winter temperature increases respiration rate, leading to consumption of the stored reserves on which early vessel formation relies (GeaIzquierdo et al. 2012; González-González et al. 2014; Pérezde-Lis et al. 2018).

In $R$. pseudoacacia, vessel size was also limited by abundant previous winter precipitation. Similar results were found in mesic forests and were attributed to soil hypoxia, which limits carbohydrate allocation to earlywood formation through enhanced consumption in roots (González-González et al. 2015). In this regard, a recent study hints that low sugar content in sapwood at the onset of dormancy may limit vessel formation and delay budburst (Pérez-De-Lis et al. 2016a). At our study site, this effect was detected only in $R$. pseudoacacia, a species sensitive to soil hypoxia (Vítková et al. 2017), while $Q$. robur seems to be better adapted to this condition.

Differences between the species were also detected in the months following winter. In $Q$. robur, temperature influenced vessel size throughout springtime, with a positive correlation in March for the largest vessels, in April for vessels of medium and small size, and in May only for small vessels. An earlier cambial reactivation due to warm springs (Pérez-de-Lis et al. 2018 ) is expected to induce formation of larger and more efficient vessels, whereas cold conditions delay growth resumption, resulting in smaller vessels and thus restricting hydraulic efficiency. High temperature in early spring may control vessel differentiation rates, too (Souto-Herrero et al. 2017). As noted by Guada et al. (2019), in $Q$. robur spring temperature determines the duration of vessel expansion, which in turn determines the final vessel size.

The response to spring temperature of $R$. pseudoacacia seemed delayed by 1 month compared to $Q$. robur. High temperature in March had a negative effect on vessel size (as occurs for winter temperature), while warm April favored the formation of larger vessels. Although we have no data about the timing of cambium resumption, we may suppose that delayed onset of growth processes might be a strategy of the species to guarantee vessel safety, and that this strategy has a double effect: (i) to minimize the risk of freeze-induced embolism due to late frost in early spring; and (ii) to produce smaller vessels (Guada et al. 2019), decreasing the risk of drought-induced cavitation during the following months.

As a consequence of recent climate changes we expected that some responses might not be stable in time (Carrer et al. 2010). While the responses of both species to previous summer and autumn were quite constant (Fig. 6), remarkable variability occurred during the dormancy period and at its end (from December to March). In $Q$. robur, the decrease in sensitivity to temperature might reflect a modification in the timing of wood formation, while $R$. pseudoacacia seems to modulate the response by varying number and size of vessels.

The responses to the 2003 May-to-September heatwave further evidenced different species behavior. This exceptional climate event did not affect the 2003 ring vessels in either species, probably because earlywood formation had occurred earlier (see observations for $Q$. robur in similar climate conditions in Pérez-de-Lis et al. 2016b). However, the harsh conditions certainly reduced transpiration, water uptake, and carbon assimilation due to stomatal closure (Granier et al. 2007) in both species, affecting growth in the following year. In ring-porous oak species, the earlyseason growth phases rely on carbon reserves (Zweifel et al. 2006), which are usually refilled during the growing season, but this hardly occurred in 2003 (Breda et al. 2006). Accordingly, the earlywood large vessels of the 2004 ring were strongly reduced in $Q$. robur (Fig. 7). Xylem traits of $R$. pseudoacacia were less affected, although the size of large vessels was slightly reduced, too. The higher resistance of the latter species to the 2003 heatwave is consistent with the other results of our analysis, showing that xylem formation is less dependent on previous-year reserves (as for diffuse-porous species, Zweifel et al. 2006) than in Q. robur (Fig. 3, Fig. 4). Moreover, R. pseudoacacia shows greater ability to cope with environmental drought also through its leaves and 
roots, which have high ecophysiological and morphological plasticity, allowing the species to perform well in drought-affected European regions (Mantovani et al. 2014; Mantovani et al. 2015). Our results confirm that this alien species is less sensitive to water shortage, and can be considered more adapted to warm and dry conditions than most Central European broadleaves trees, including Q. robur (Vítková et al. 2017).

We cannot exclude that some of the differences detected between the two species might partly be due to the diverse size and age of the sampled trees. Indeed, $Q$. robur trees were bigger and older than R. pseudoacacia trees (Tab. 1). In any case, the size and age of the investigated trees are representative of the current state of the Reserve, where $Q$. robur has dominated the forest canopy for over a century and $R$. pseudoacacia established around 1940 (Motta et al.2009). This situation is, indeed, characteristic ofmost plain forests in Northern Italy. The species climate responses identified here might be relevant for understanding future forest dynamics in the whole area. In a previous study, Motta et al. (2009) suggested that the best strategy for controlling black locust spread is to avoid disturbances that favor its colonization. Longerlived and more shade-tolerant species should naturally replace it. In addition to this consideration, they raised questions about the effects of climate change and spreading oak decline on such natural dynamics. Our results suggest that the expected increase in drought events might negatively affect oak. This would result in an additional benefit for black locust, which not only is less affected by climate change but also could take advantage of gaps deriving from oak decline and mortality. Our interpretation is consistent with those of other studies, indicating that climate change might enhance $R$. pseudoacacia competitiveness, increasing its distribution in Europe and delaying natural replacement by native species (Dyderski et al. 2018; Kleinbauer et al. 2010; Nadal-Sala et al. 2017).

\section{Conclusion}

Our findings show diverse influences of climate on the hydraulic-related xylem traits of co-occurring $R$. pseudoacacia and $Q$. robur, likely related to their species-specific ecological requirements. Quercus robur showed typical ring-porous behavior: vessel size and number were mostly related to previous summer precipitation and autumn-winter temperatures, which likely affect the accumulation of reserves used for xylem formation. Indeed, events such as the 2003 summer heatwave had a strong impact on vessels formed the following year. In contrast, $R$. pseudoacacia produced smaller, less efficient, but safer vessels. The species modulated its responses to climate by producing either a higher number of small vessels or a lower number of large ones, sometimes modulating ring porosity, too. Different responses to winter precipitation suggest that $R$. pseudoacacia is more sensitive to water excess and soil hypoxia.
The xylem plasticity of R. pseudoacacia enables it to cope better with both inter-annual climate variations and drought extreme events than $Q$. robur does. Considering foreseen intensification of extreme events (drought spells and heatwaves), these differences could favor this alien species over the native coexisting one, even in a mesic site. This might slow down the natural succession which should lead to the regression of the pioneer and invasive black locust by later stage species such as the oak. Comparative investigation of xylem response to climate of native and alien species, associated with other physiological and ecological aspects, will help better understand climate influence on their growth, and assess the future spread of alien tree species in Europe.

Funding information This study was supported by grants from the University of Pavia: Functional and structural characterization of tree species inside the Natural Reserve "Siro Negri," funded by the Italian Ministry for Environment and Land and Sea Protection. Daniele Castagneri received funding from the European Union's Horizon 2020 research and innovation program under grant agreement $\mathrm{N}^{\circ} \mathrm{H} 2020$ MSCA-IF-2017-788951.

\section{Compliance with ethical standards}

Data availability The dataset generated during the current study is available from the corresponding author upon reasonable request.

Conflict of interest The authors declare that they have no conflict of interest.

Statement on ethical approval The field work and the sampling activities within "Siro Negri" State Natural Reserve were conducted under the explicit permission of the Director of the protected area.

\section{Annexes}

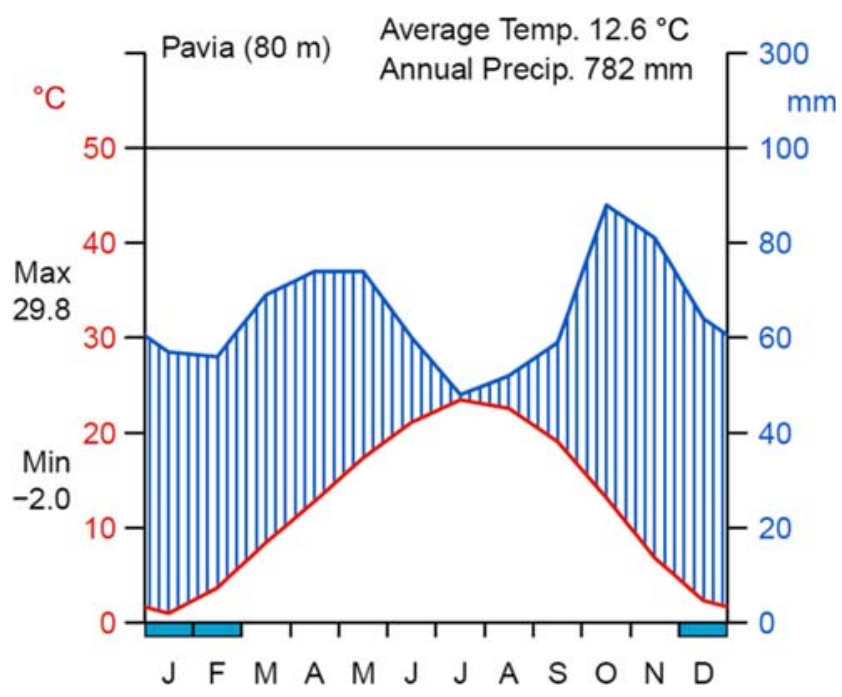

Fig. 8 Climate diagram from Pavia meteorological station 

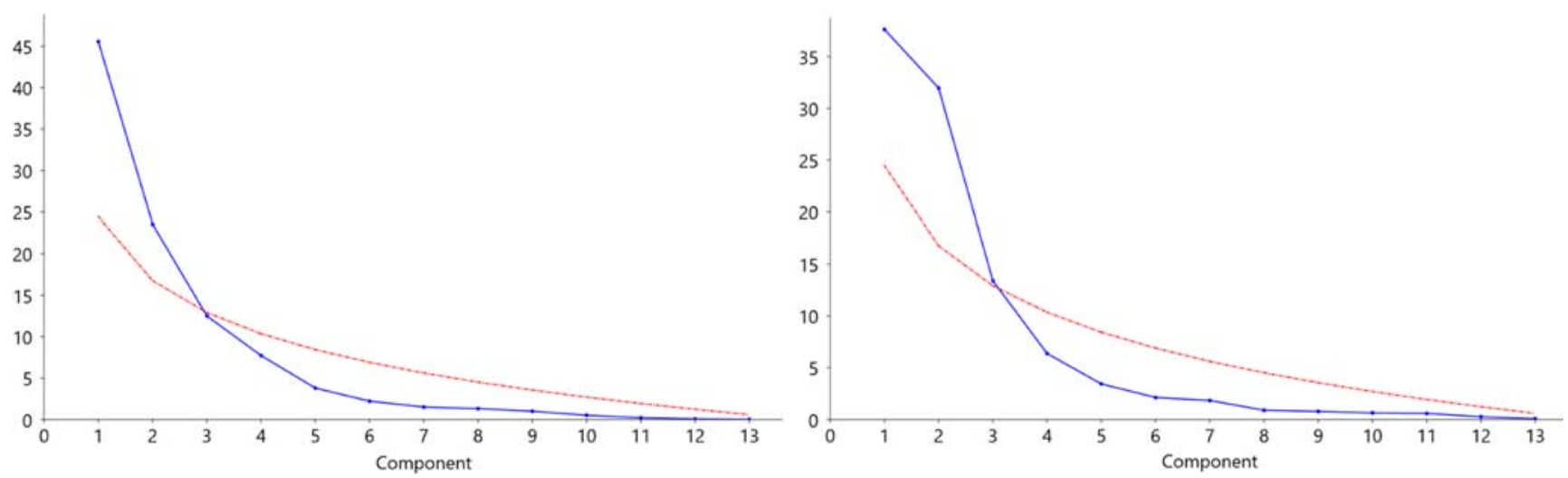

Fig. 9 Scree plot from PCA of tree-ring width and vessel parameters. The Y-axis represents the percentage of variance explained by each component (solid line). The dashed line represents the superimposed Broken-Stick Model

\section{Quercus robur}
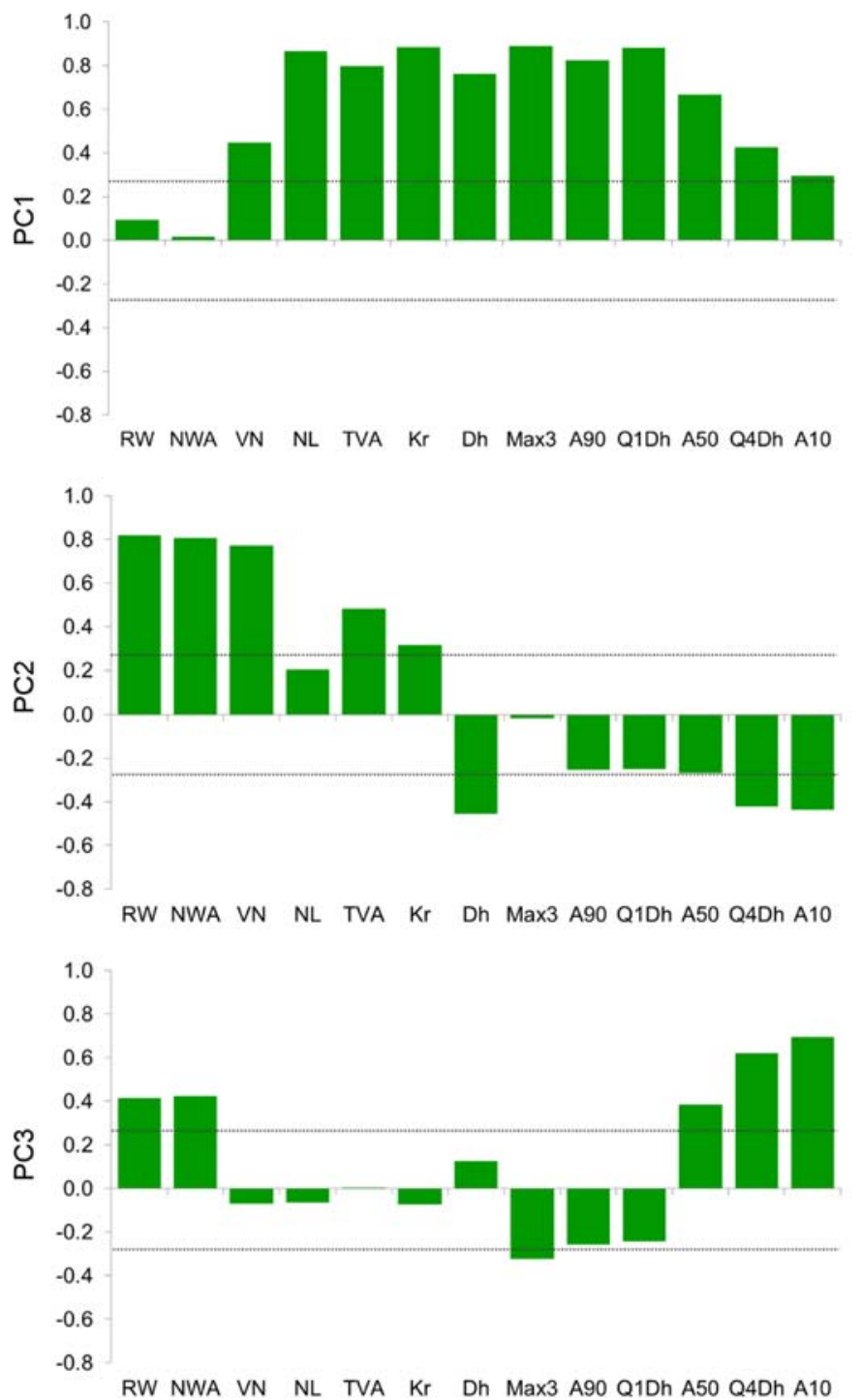

Robinia pseudoacacia

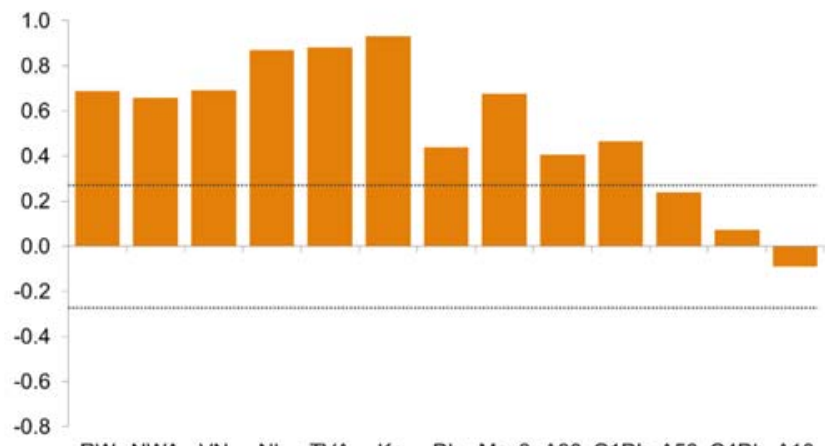

RW NWA VN NL TVA Kr Dh Max3 A90 Q1Dh A50 Q4Dh A10

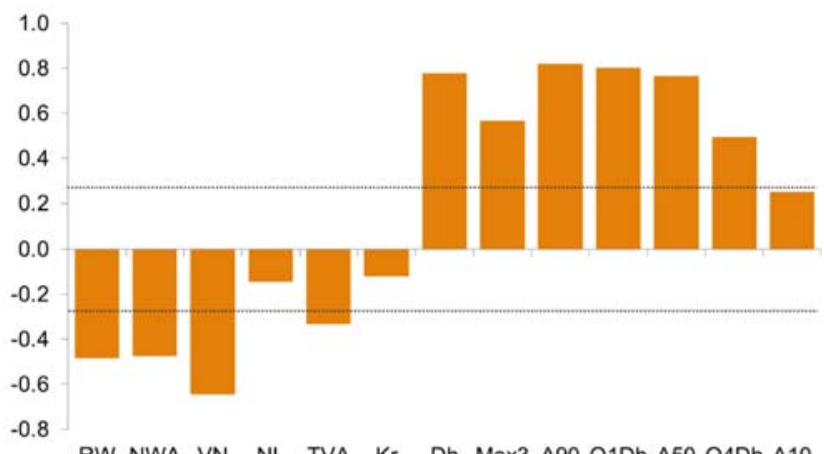

RW NWA VN NL. TVA Kr Dh Max3 A90 Q1Dh A50 Q4Dh A10

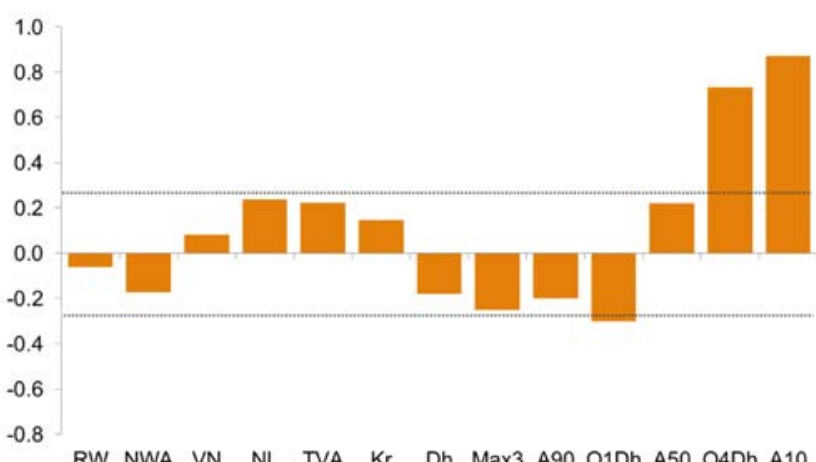

Fig. 10 Pearson's correlations between tree-ring and vessel parameters and the first three principal components. Dotted lines indicate the level of significant correlation. Acronyms are explained in Table 2 
Fig. 11 Pearson's correlations between ring width and vessel chronologies for each species. Correlation values are coded according to the key at the bottom. Acronyms are explained in Table 2

Fig. 12 Inter-species correlations for each tree-ring width and vessel chronology. Dotted lines indicate the level of significant correlation and solid bars refer to significant values. Acronyms are explained in Table 2
Quercus robur
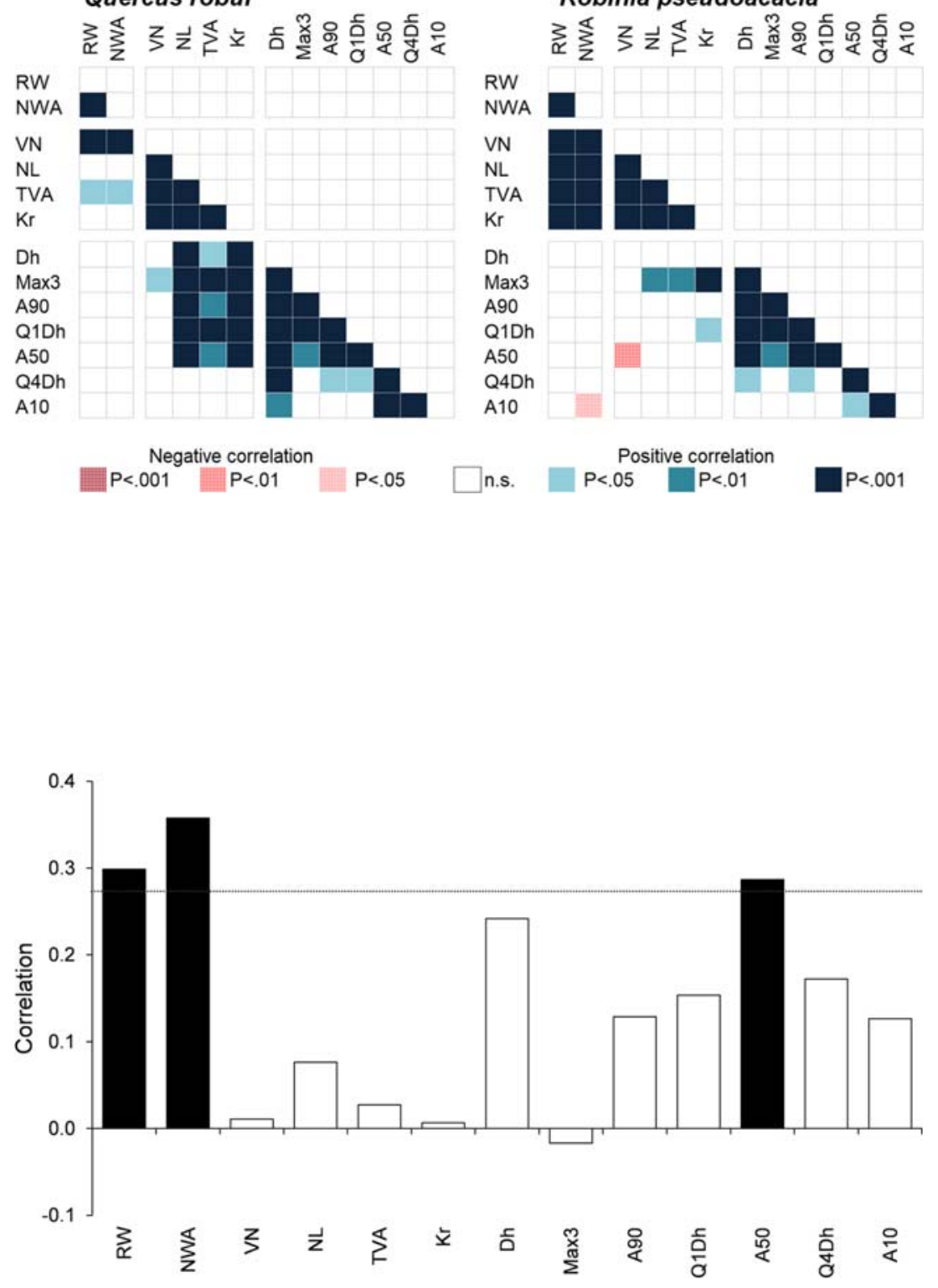


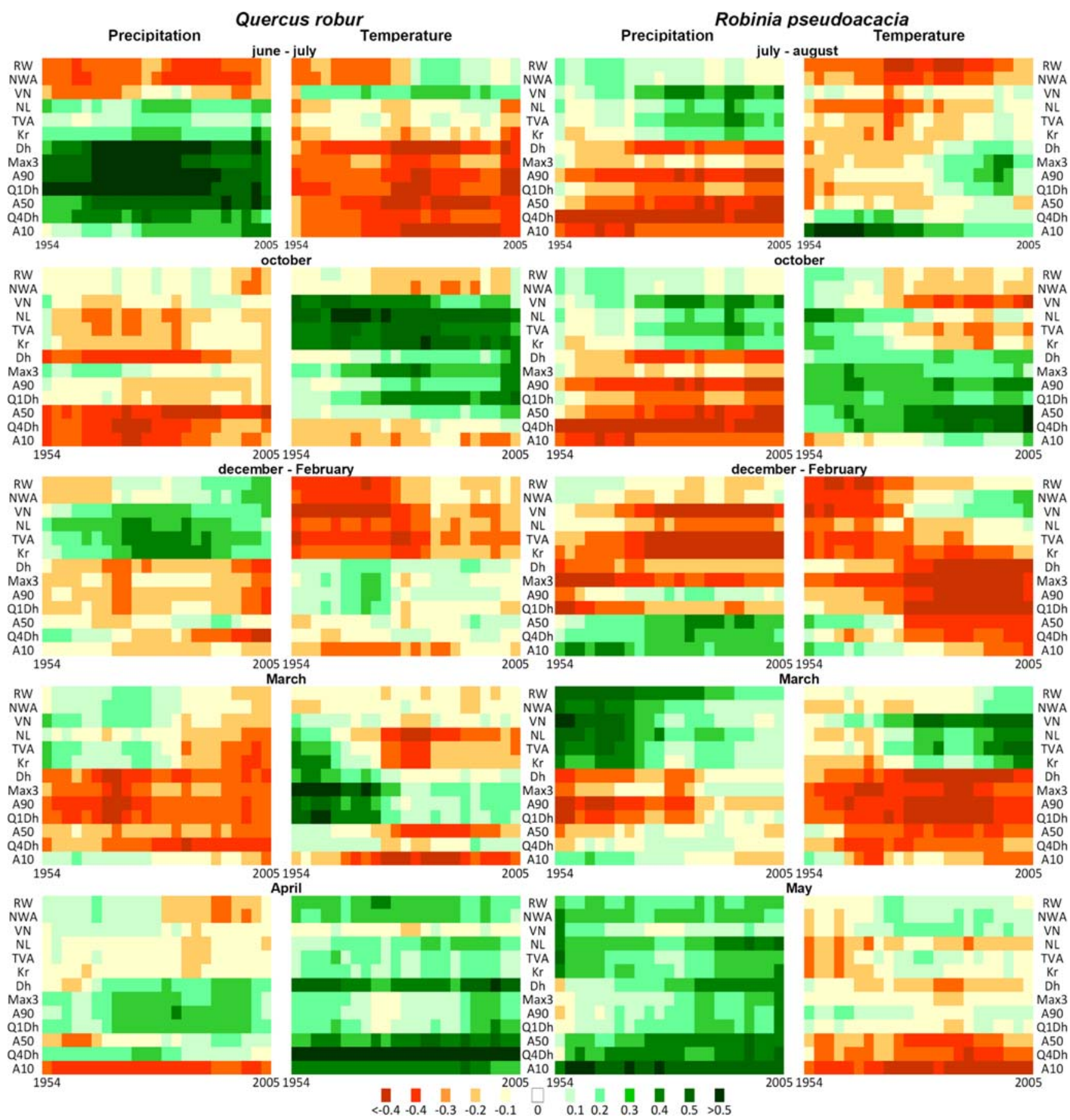

Fig. 13 Moving correlation with a 30-year window between all the anatomical parameters and the most significant climatic variables. Months of the previous year are in lowercase letters. $R$ values are coded according to the key at the bottom. Acronyms are explained in Table 2

\section{References}

Akhmetzyanov L, Buras A, Sass-Klaassen U, den Ouden J, Mohren F, Groenendijk P, García-González I (2019) Multi-variable approach pinpoints origin of oak wood with higher precision. J Biogeogr 2019:1-15

Alla AQ, Camarero JJ (2012) Contrasting responses of radial growth and wood anatomy to climate in a Mediterranean ring-porous oak: implications for its future persistence or why the variance matters more than the mean. Eur J For Res 131:1537-1550

Aloni R, Zimmermann MH (1983) The control of vessel size and density along the plant axis - a new hypothesis. Differentiation 24:203-208

Aniol RW (1987) A new device for computer assisted measurement of tree-ring widths. Dendrochronologia 5:135-141

Biondi F, Waikul K (2004) DENDROCLIM2002: a C++ program for statistical calibration of climate signals in tree-ring chronologies. Comput Geosci 30:303-311 
Bonan GB (2008) Forests and climate change: forcings, feedbacks, and the climate benefits of forests. Science 320:1444-1449

Bréda N, Granier A (1996) Intra and interannual variations of transpiration, leaf area index and radial growth of a sessile oak stand (Quercus petraea). Ann For Sci 53:521-536

Breda N, Huc R, Granier A, Dreyer E (2006) Temperate forest trees and stands under severe drought: a review of ecophysiological responses, adaptation processes and long-term consequences. Ann For Sci 63:625-644

Bussotti F, Pollastrini M, Holland V, Brüggemann W (2015) Functional traits and adaptive capacity of European forests to climate change. Environ Exp Bot 111:91-113

Carrer M, Nola P, Motta R, Urbinati R (2010) Contrasting tree-ring growth to climate responses of Abies alba toward the southern limit of its distribution area. Oikos 119:1515-1525

Carrer M, von Arx G, Castagneri D, Petit G (2015) Distilling allometric and environmental information from time series of conduit size: the standardization issue and its relationship to tree hydraulic architecture. Tree Physiol 35:27-33

Castagneri D, Garbarino M, Nola P (2013) Host preference and growth patterns of ivy (Hedera helix L.) in a temperate alluvial forest. Plant Ecol 214:1-9

Castagneri D, Petit G, Carrer M (2015) Divergent climate response on hydraulic- related xylem anatomical traits of Picea abies along a 900-m altitudinal gradient. Tree Physiol 35:1378-1387

Castagneri D, Regev L, Boaretto E, Carrer M (2017) Xylem anatomical traits reveal different strategies of two Mediterranean oaks to cope with drought and warming. Environ Exp Bot 133:128-138

Cavalieri MA, Sack L (2010) Comparative water use of native and invasive plants at multiple scales: a global meta-analysis. Ecology 91(9): 2705-2715

Ciais P, Reichstein M, Viovy N, Granier A, Ogee J, Allard V, Aubinet M, Buchmann N, Bernhofer C, Carrara A, Chevallier F, De Noblet N, Friend AD, Friedlingstein P, Grünwald T, Heinesch B, Keronen P, Knohl A, Krinner G, Loustau D, Manca G, Matteucci G, Miglietta F, Ourcival JM, Papale D, Pilegaard K, Rambal S, Seufert G, Soussana JF, Sanz MJ, Schulze ED, Vesala T, Valentini R (2005) Europe-wide reduction in primary productivity caused by the heat and drought in 2003. Nature 473:529-533

Cierjacks A, Kowarik I, Joshi J, Hempel S, Ristow M, von der Lippe M, Weber E (2013) Biological flora of the British Isles: Robinia pseudoacacia. J Ecol 101:1623-1640

Cook ER, Krusic PJ (2005) Program Arstan, a tree-ring standardization program based on detrending and autoregressive time series modelling, with interactive graphics. Tree-ring Lab Lamont Doherty Earth Obs Columbia University

Cook ER, Peters K (1981) The smoothing spline: a new approach to standardizing forest interior tree-ring width series for dendroclimatic studies. Tree-Ring Bull 41:45-53

Cruiziat P, Cochard H, Ameglio T (2002) Hydraulic architecture of trees: main concepts and results. Ann For Sci 59:723-752

De Micco V, Carrer M, Rathgerber CBK, Camarero JJ, Voltas J, Cherubini P, Battipaglia G (2019) From xylogenesis to tree rings: wood traits to investigate tree response to environmental changes. IAWA J 2019:2-29

Dyderski MK, Paz S, Frelich LE, Jagodzinski AM (2018) How much does climate change threaten European forest tree species distributions? Glob Change Biol 24:1150-1163

Fonti P, García-González I (2008) Earlywood vessel size of oak as a potential proxy for spring precipitation in Mesic sites. J Biogeogr 35(12):2249-2257

Fonti P, Solomonoff N, García-González I (2007) Earlywood vessels of Castanea sativa record temperature before their formation. New Phytol 173:562-570
Fonti P, Eilmann B, García-González I, von Arx G (2009) Expeditious building of ring-porous earlywood vessel chronologies without loosing signal information. Trees 23:665-671

Fonti P, von Arx G, García-González I, Eilmann B, Saas-Klaassen U, Gärtner H, Eckstein D (2010) Studying global change through investigation of the plastic responses of xylem anatomy in tree rings. New Phytol 185:42-53

Fritts HC (1976) Tree-rings and climate. Academic press, London

García-González I, Eckstein D (2003) Climatic signals of earlywood vessels of oak on a maritime site. Tree Physiol 23:497-504

García-González I, Fonti P (2008) Ensuring a representative sample of earlywood vessels for dendroecological studies: an example from two ring-porous species. Trees 22:237-244

García-González I, Souto-Herrero M, Campelo F (2016) Ring-porosity and earlywood vessels: a review on extracting environmental information through time. IAWA J 37(2):295-314

Gärtner H, Schweingruber FH (2013) Microscopic preparation techniques for plant stem analysis. Remagen Kessel Publishing House

Gea-Izquierdo G, Fonti P, Cherubini P, Martin-Benito D, Chaar H, Canellas I (2012) Xylem hydraulic adjustment and growth response of Quercus canariensis Willd to climatic variability. Tree Physiol 32:401-413

Giorgi F, Lionello P (2008) Climate change projections for the Mediterranean region. Glob Planet Change 63:90-104

González-González BD, Rozas V, García-González I (2014) Earlywood vessels of the sub-Mediterranean oak Quercus pyrenaica have greater plasticity and sensitivity than those of the temperate $Q$. petraea at the Atlantic-Mediterranean boundary. Trees - Struct Funct 28:237252

González-González BD, Vázquez-Ruiz RA, García-González I (2015) Effects of climate on earlywood vessel formation of Quercus robur and $Q$. pyrenaica at a site in the northwestern Iberian Peninsula. Can Journal For Res 45(6):698-709

Granier A, Reichstein M, Bréda N, Janssens IA, Falge E, Ciai P, Grunwald T, Aubinet M, Berbigier P, Bernhofer C, Buchmann N, Facini O, Grassi G, Heinesch B, Ilvesniemi H, Keronen P, Knohl A, Köstner B, Lagergren F, Lindroth A, Longdoz B, Loustau D, Mateus J, Montagnani L, Nys C, Moors E, Papale D, Peiffer M, Pilegaard K, Pita G, Pumpanen J, Rambal S, Rebmann C, Rodrigues A, Seufert G, Tenhunen J, Vesala T, Wang Q (2007) Evidence for soil water control on carbon and water dynamics in European forests during the extremely dry year: 2003. Agric For Meteorol 143:123-145

Guada G, Vázquez-Ruiz RA, García-González I (2019) Response patterns of xylem and leaf phenology to temperature at the southwestern distribution boundary of Quercus robur: a multi-spatial study. Agric For Meteorol 269-270:46-56

Hacke UG, Sperry JS (2001) Functional and ecological xylem anatomy. Perspect Plant Ecol Syst 4(2):97-115

Hacke UG, Spicer R, Schreiber SG, Plavcová L (2017) An ecophysiological and developmental perspective on variation in vessel diameter. Plant Cell Env 40:831-845

Hanewinkel M, Cullmann DA, Schelhaas MJ, Nabuurs GJ, Zimmermann NE (2013) Climate change may cause severe loss in the economic value of European forest land. Nat Clim Chang 3:203-207

Harris I, Jones PD, Osborn TJ, Lister DH (2014) Updated high-resolution grids of monthly climatic observations - the CRU TS3.10 dataset. Int J Climatol 34:623-642

Jackson DA (1993) Stopping rules in principal components analysis: a comparison of heuristical and statistical approaches. Ecology 74: 2204-2214

Kitin P, Funada R (2016) Earlywood vessels in ring-porous trees become functional for water transport after bud burst and before the maturation of the current-year leaves. IAWA J 37:315-331

Kleinbauer I, Dullinger S, Peterseil J, Essl F (2010) Climate change might drive the invasive tree Robinia pseudacacia into nature reserves and endangered habitats. Biol Conserv 143:382-390 
Knüsel S, Conedera M, Rigling A, Fonti P, Wunder J (2015) A tree-ring perspective on the invasion of Ailanthus altissima in protection forests. For Ecol Manag 354:334-343

Kutscha NP, Sachs IB (1962) Colour tests for differentiating heartwood and sapwood in certain softwood tree species. USDA, Forest Products Laboratory, University of Wisconsin, Report No. 2264

Lebourgeois F, Mérian P, Courdier F, Ladier J, Dreyfus P (2012) Instability of climate signal in tree-ring width in Mediterranean mountains: a multi-species analysis. Trees 26:715-729

Lévesque M, Saurer M, Siegwolf R, Eilmann B, Brang P, Bugmann H, Rigling A (2013) Drought response of five conifer species under contrasting water availability suggests high vulnerability of Norway spruce and European larch. Glob Chang Biol 19:3184 3199

Lloret F, Keeling EG, Sala A (2011) Components of tree resilience: effects of successive low-growth episodes in old ponderosa pine forests. Oikos 120:1909-1920

Mantovani D, Veste M, Freese D (2014) Black locust (Robinia pseudoacacia L.) ecophysiological and morphological adaptations to drought and their consequence on biomass production and wateruse efficiency. New Zeal J For Sci 44:29

Mantovani D, Veste M, Boldt-Burisch K, Fritsch S, Koning LA, Freese D (2015) Carbon allocation, nodulation, and biological nitrogen fixation of black locust (Robinia pseudoacacia L.) under soil water limitation. Ann For Res 58(2):259-274

Martínez-Sancho E, Dorado-Liñán I, Heinrich I, Helle G, Menzel A (2017) Xylem adjustment of sessile oak at its southern distribution limits. Tree Physiol 37:903-914

Michelot A, Simard S, Rathgeber C, Dufrêne E, Damesin C (2012) Comparing the intra-annual wood formation of three European species (Fagus sylvatica, Quercus petraea and Pinus sylvestris) as related to leaf phenology and non-structural carbohydrate dynamics. Tree Physiol 32:1033-1045

Motta R, Nola P, Berretti R (2009) The rise and fall of the black locust (Robinia pseudoacacia L.) in the "Siro Negri" forest reserve (Lombardy, Italy): lessons learned and future uncertainties. Ann For Sci 66:410

Nadal-Sala D, Sabaté S, Sánchez-Costa E, Poblador S, Sabater F, Gracia C (2017) Growth and water use performance of four co-occurring riparian tree species in a Mediterranean riparian forest. For Ecol Manag 396:132-142

Nola P (1996) Climatic signal in earlywood and latewood of deciduous oaks from northern Italy. In: Dean JS, Meko DM, Swetnam TW (eds) Tree Rings. Environment and Humanity, Radiocarbon pp, pp 249-258

Olson M, Soriano D, Rosell JA, Anfodillo T, Donoghue MJ, Edwards EJ, León-Gómez C, Dawson T, Camarero Martínez JJ, Castorena M, Echeverría A, Espinosa CI, Fajardo A, Gazol A, Isnard S, Lima RS,
Marcati CR, Méndez-Alonzo R (2018) Plant height and hydraulic vulnerability to drought and cold. PNAS 115(29):7551-7556

Pérez-De-Lis G, García-González I, Rozas V, Olano JM (2016a) Feedbacks between earlywood anatomy and non-structural carbohydrates affect spring phenology and wood production in ringporous oaks. Biogeosciences 13(19):5499-5510

Pérez-de-Lis G, Rossi S, Vázquez-Ruiz RA, Rozas V, García-González I (2016b) Do changes in spring phenology affect earlywood vessels? Perspective from the xylogenesis monitoring of two sympatric ringporous oaks. New Phytol 209:521-530

Pérez-de-Lis G, Olano JM, Rozas V, Rossi S, Vázquez-Ruiz RA, GarcíaGonzález I (2017) Environmental conditions and vascular cambium regulate carbon allocation to xylem growth in deciduous oaks. Funct Ecol 31(3):592-603

Pérez-de-Lis G, Rozas V, Vázquez-Ruiz RA, García-González I (2018) Do ring-porous oaks prioritize earlywood vessel efficiency over safety? Environmental effects on vessel diameter and tyloses formation. Agric For Meteorol 248:205-214

Sartori F (1984) Les forêts alluviales de la basse vallée du Tessin (Italie du nord). In: Cramer J (ed) Colloques phytosocologiques: la végétation des forêts alluviales, pp 201-216

Schmitt U, Möller R, Eckstein D (2000) Seasonal wood formation dynamics of beech (Fagus sylvatica L.) and black locust (Robinia pseudoacacia L.) as determined by the "pinning" technique. J Appl Bot 74:10-16

Schweingruber FH (1990) Anatomy of European woods. Paul Haupt, Bern

Souto-Herrero M, Rozas V, García-González I (2017) A 481-year chronology of oak earlywood vessels as an age-independent climatic proxy in NW Iberia. Glob Planet Change 155:20-28

Tessier L, Nola P, Serre-Bachet F (1994) Deciduous Quercus in the Mediterranean region: tree-ring/climate relationships. New Phytol 126:355-367

Tyree MT, Zimmermann MH (2002) Xylem structure and the ascent of sap. Springer-Verlag, Berlin, Heidelberg, NewYork

Vítková M, Müllerová J, Sádlo J, Pergl J, Pyšek P (2017) Black locust (Robinia pseudoacacia) beloved and despised: a story of an invasive tree in Central Europe. For Ecol Manag 384:287-302

von Arx G, Carrer M (2014) ROXAS - a new tool to build centuries-long tracheid-lumen chronologies in conifers. Dendrochronologia 32: 290-293

Zweifel R, Zimmermann L, Zeugin F, Newbery DM (2006) Intra-annual radial growth and water relations of trees: implications towards a growth mechanism. J Exp Bot 57:1445-1459

Publisher's note Springer Nature remains neutral with regard to jurisdictional claims in published maps and institutional affiliations. 